\title{
The Importance of Marriage and Family in the Narratives of Adult Children of Divorced Parents
}

\begin{abstract}
We live in a world where all the beliefs, passed from one generation to another, all our values are being redefined. Notions of marriage and family also receive different meaning. Today, the term „marriage” extends its meaning, not limiting itself to the naming of "entangled" couples by legal or church law. It also refers to people who consider themselves to be linked with each other, not only by legal terms, people whose relationships are different on various levels from the traditionally understood marriage. However, for generations we have invariably associated the notion of family with love, support, warmth and place of meeting with people important and valuable to us, on who we can count on and expect some help when we need it.

Such an importance given to the family was revealed in my interviews with the adult children of divorced parents. People involved in my research often stressed the great value they associate with this smallest social group. Statements about marriage and family seem to be firmly rooted in the past experiences, which is reflected in their convictions concerning the impermanence of marriage and family systems. On the other hand, one can notice an intense longing for what they could not experience in the past - a stable and happy family. I believe that in the context of the presented narrations one can conclude that the divorce of the parents as the critical life event is strongly written in the identity of „the children of divorce”. It highly influences their attitudes towards marriage, family and relationships in general.
\end{abstract}

Key words: adult children, divorce, family, marriage.

\section{Introduction}

Analyzing the literature on the divorce we can identify three ways of recognizing this phenomenon by various authors. The first one, especially 


\section{Maja Piotrowska}

popular among Polish researchers, is the position of treating the divorce as a pathology in the family (eg. Franciszek Adamski, Henryk Cudak). Broadly described, negative consequences of family breakdown, both in the context of the spouses, and, perhaps above all, the child lead to such an understanding of divorce. The second one, absent in Poland, and appearing in foreign publications of the 60's, is a position that allows us to perceive divorce as a positive event in the people's life, restoring them freedom which they lost as a result of marriage. However, the third one considers divorce as a critical life event. A characteristic feature of critical life events is their ambivalences. Facing such situation, the person will face certain tasks, which may be developmental (creating person's „second chance"), but which may also introduce the risk of pathology. So, here we have to deal with both danger and threat, but also with the opportunity and the possibility of human development. Critical event also has other features, in which the phenomenon of divorce may be considered. These are: the instability, separation from the everyday course of events and urge to the application of completely new ways of doing things than before. On the way to become a critical one, every event in life has to be emotionally significant to the individual, for example it must be associated with important values. Divorce shows all of these features, so surely we can consider it as the critical event [see Beisert 2000]. In the context of assumptions about life's crises, it seems important to ask questions concerning the extent of its impact on the participating members of family. This mainly concerns the consequences of divorce for children, because their situation is considerably different from that of their parents, because they do not take part in making decisions about the fate of the family, but face all the consequences of those decisions. Hence, a divorce for a child can be an extrinsic critical event, with low controllability, characterized in that their parents are the trigger. The event also has its critical space-and-time limits, because the imbalance caused by it cannot last forever. In reference to the divorce, the space is clearly defined - it is set by life of a particular family. Time limits are often very individual (depending on the extent of the effects of divorce), but the literature indicates about annual or biennial one that can sometimes take up to four years for a return to equilibrium in the case of adults (spouses). But for a child whose parents divorced overworking losses may even reach 10 to 15 years after the event. As explained by the author of "Second Chance. Men, Women and Children a Decade After Divorce" Judith S. Wallerstein i Sandra Blakeslee, child in every moment of his/her life is exposed to long-term effects of divorce of the parents [see Wallerstein, Blakeslee 2006]. Dealing with the situation of divorce and post-divorce is a long process that involves six stages 1) realizing the reality of parents' marriage breakdown, 2) detachment from the conflict between parents and the resumption of the normal aspirations, 3) dealing with the losses resulting from the divorce of parents, 4) 
coping with anger and self-blame 5) accepting the life of the divorce of parents and 6) reaching the readiness to enter interpersonal relationships. The last, sixth stage of child's coping with the divorce of parents, assumes dealing with the problem of genuine participation in emotional relationships with other people and ability to love and trust them. It is the most important and difficult task for the social development of children who grow up. The sixth stage collects and integrates the efforts of the previous five steps, allowing to look more maturely and with some distance at the problem of divorce parents [Franicka 1999, pp. 67-71]. Positive overwork of the latter task leads to a psychological release from the past.

The long-term studies of J.S. Wallerstein shows that for young, growing-up people, their parents' divorce is the most important event of childhood. It highly effects the personality, attitudes, relationships and self-esteem of an adolescent man. Over time, these effects can be modified by subsequent experiences of life, however they involve themselves in a complex weave of general experience and functioning of already adult child. The researcher also claims that entering the period of early adulthood by people from families affected by parental divorce is more difficult than their peers from complete families and is also loaded with a big, negative baggage of their childhood experience [see Wallerstein, Blakeslee 2006]. Parents' divorce may effects on their attitudes towards marriage, having family, and the importance they attach to these two important spaces of human existence.

The period of early adulthood is a time of the development of intimate relationships, shaping relationships with other people, full of maturity, tolerance of difference and sensitivity. Socially mature adult is able to communicate effectively with others and to show sensitivity to the needs other than his or her own. A person is developing and also defines the friendship-and-love relationships that he or she creates. It requires sacrifice for others, starting with getting out of one's shell and opening up to another man.

\section{Methodological basis of my research}

There were nineteen people who took part in my qualitative-natured research on the importance of parental divorce from the perspective of the adult lives of their children. Among them were fourteen women and five men. All of them were in a period called ,adulthood" by Erik Erikson (between 20 to 35 years). The basis for my research was a qualitative interview studied by Steinar Kvale [Kvale 2004]. In addition, as a complementary technique for the research process, I used family photographs, which narrators brought to the meetings. Also through observation of my interlocutors I was able to register all the levels of non-verbal realm, existing beyond the spoken words. 


\section{The importance of marriage in the narratives of adult children of divorce}

Marriage is the subject of interest to many researchers. Educators, psychologists, sociologists, and ethnographers deal with its substance and content. Reviewing the literature on the subject one can see that today we expect much more from marriage, a lot more than we did in the previous years, decades and centuries. Unfortunately I think that today at the same time we give less respect to this kind of relationship (which can be observed by reviewing the statistics of divorce and the reasons claimed by the people - often so trivial - that determine the marriage breakdown).

Two kinds of opinions about marriage as an institution were revealed during the conversations with the adult children of divorce. I divided them as the conservative, traditional views and opinions considering marriage as a primarily formal, legally sanctioned relationship and as the liberal views, where the concept of free relationship has become not only acceptable, but also declared as the form in which persons intend to have sex with their partners.

In remarks on the marriage my interlocutors stressed that they would like to create a permanent and stable relationships that would not be destroyed by the decision about divorce. They admire couples who have been married for 30, 40 years (as opposed to the their parents' marriage) and who despite difficulties and temporary problems, managed to overcome their weaknesses together, because love and commitment was stronger. According to these narratives, marriage is defined as a relationship between two persons legalized either via a civil contract or by ecclesiastical law. These people do not allow to think that they could live in a free relationship without any obligation and sacramental oath. They give great importance for marriage understood in this way, since, according to them, it involves an important decision with consequences for the whole life. They told me:

"I'm afraid, I'm afraid of marriage for sure, but, on the other hand, I would really like to get married some day. Therefore, I am afraid, because now we can hear that people aren't able to withstand 20 years together. I'd really like to have such a marriage like my grandparents' one. They have been together for 40 years and they still love each other so much, it's really pleasant to see them. Being with them I've never heard a quarrel, NEVER. Even when they are exchanging their views they do it so quietly that no one will feel guilty, no one has ever heard that there have been some sort of dispute between them. I think that such a marriage as an institution is needed, because I don't know... maybe it is so traditional. But people consider this as just living with each other, but I don't think about it in this way. This is a moment in a woman's life, surely in a man's too, but I'm talking from the perspective of myself that I feel so important in this man's life. That 
besides the fact that they have been together for so many years, or even many months, it is such a thing, such a special, such a thing, what one remembers, what it's worth to mention, if it can be developed"' (female, age 21).

"For me, marriage was always important. I've always admired those couples who, for example, celebrate $20^{\text {th }}$ or $30^{\text {th }}$ wedding anniversary, in spite of... you know everywhere there are some quarrels, but whenever there is a problem, those couple sit down together and talk, hug themselves... When some disease appears, they will come to support each other in those very difficult moments. And I admire, I really admire those marriages, like my aunt's one. Because my uncle was in his forties, he probably hadn't been at home for 5 years or so and, normally he returned to my aunt, and this marriage somehow endured, I do not know if he would come back just for night or something like this, I simply don't know, they used to live at a distance, but now they are together. They came back to each other about 5 years ago. They are together and it is really good, they live in the same flat, they don't quarrel, they manage to endure the difficulties. It is also something important for me, because some people simply give up, when they find out that they were cheated or deceived. I've never wanted to be a divorcee, although nowadays it is normal to be divorced, every third or fourth Polish woman gets divorced and then gets married again, but myself, when I got married, I would like to be with my husband till the end, endure all those difficulties and, I must be aware that now, if I chose someone inappropriate, it will end with divorce, I'm pretty sure" (female, age 23).

"My personal opinion is that marriage is an appropriate solution, because virtually from the beginning... you have to come back somewhere. For what do we live? Right. For what do we live? Where does it come from that a child is the next step to be taken, right, then he or she also becomes a father or a mother, and like in a circle of successive generations, thus it is needed. But the institution itself, as I say, is changing. It seems to me that our times causes the situations where there are so many couples who bring up children without being married, and for them... it's like there is no problem with that, but it is still not accepted by society. It also has an impact on how we perceive it, how externally strong we are, and do we accept it or not. I'd say that I like both theories, the one involving raising children without being married, and the one with being so, but looking through the perspective of a young person and cultural grounds, I would prefer to keep this trend, of the family with the marriage with the attitude toward everything in this relationship" (male, 31 years).

These narratives give marriage the traditional dimension. In these statements, the term "marriage" is understood as a relationship of two people linked by legal union, or by the church. Today's socio-cultural changes, which we are witnessing and participating in, bring a new style of family life - a free relationship (often 
called, rather pejoratively, "concubinage" or "cohabitation"), in which the partners live together without being married to each other by civil or ecclesiastical means. Famililogists report [see Kawula 2006] that in Poland there is an increasing number of new family constellations, and in consequence it leads to an increased number of children being raised in these new forms of family or quasi-family life. The causes of this patchiness within the contemporary forms of family marriage and, more recently, growing popularity and social acceptance for such a lifestyle, are sought by the educators in the transformation of post-industrial era, especially related to the ideology of liberalism and individualism within the forms of activity in the family and the progressive autonomy of its members [comp. Pszczółka 2005; Tyszka 2001].

Many authors of works devoted to the family see the idea of free relationship as a major threat to traditional marriage - a family living. But I think that it should not be demonized so much, because in our society marriage is still the dominant relationship. Many young people get married, decide to start a family, others often formalize their relationship, even after several years of living together without marriage. However, I think that the most important issue is the happiness and mutual love between two people, which cannot be guaranteed by any document but only by hard work related to continuous dialogue with another person, permanent deepening of mutual relations, openness in communicating one's desires and needs, and the ability to compromise. Polish youths, questioned by Zofia Gawlina [2006], indicates marriage and family life as a highly respected value in their lives.

The vast majority $(79.4 \%)$ agrees that marriage is a permanent connection of two people in love, and $14.2 \%$ attaches great importance to stability, which according to them, the institution of marriage gives.

Among people involved in my research there were also statements which revealed the view that before marriage, people should live together in order to better know each other, to check whether they can live together in the reality of everyday life, whether they can still love each other - before they take the final decision to legalize their relationship. Such an understanding of cohabitation, as Anna Kwak [2005] indicates, is a new kind of engagement, "going out together". This form of premarital life, on a trial basis, has, I believe, to protect many people against rush, simplistic choice based only on the knowledge about one's partner gained through occasional meetings, during which everybody tries to show themselves at their best, when actually they do not know each other at all. What these couples depend on is only the imagination of the ideal partner, which seems to be always in a controlled, time-limited situations and places. One of the men expressed his opinion on this matter in the following words:

"I believe that people should live together before marriage, you should try to live together, because sometimes it is the issue of some really strange matters that 
decides whether the couple could later get on. There should be such an attempt, of course based on trust. And on responsibility as well. We need to know what we both want. Not that we are trying to show that we want to be adults, only that we really want to see how it will be later. I believe that such an attempt is better than simply taking risk because then things won't screw up, like, you know, first there is church wedding and then they realize that they don't match for various reasons. So what then? Yes, it really sucks" (male, age 31).

Another woman, who took part in the research, said:

"Well, I think most people should be together and then get married, but they should do something more before this like... first living together, for about two years for example, because when a couple is simply going out with each other, they meet in controlled situations. Nobody gets up angry because of this or that. Those couples only save the money for some flat, then they live together and then - surprise! - suddenly a big disappointment appears, cause one of the partners has some habits. First, they were going out, giving flowers, talking bollocks - it's true, everyone is trying at the beginning and then unfortunately not. Having a common household and everyday's reality, there's not enough for this or that. I know it. My sister... although I shall say that she succeeded, because her husband maybe isn't perfect, but I think he is a very good man and I really like him and I know that he loves her very much and he would never cheat on her, and he looks at her like at the picture. And I'm aware of the matter that he sometimes isn't talkative when it concerns some issues, but I know that he loves her very much, and besides, one can clearly see it. She really hit the mark, if you know what I mean" (female, age 23).

What I also considered as typical for this type of statement was an invoked image of marriage (sisters, grandparents, friends, aunts, never the parents), and according to my narrators, the image having all the features that should be characteristic of a good, stable and a lasting marriage between two people. A relationship that has a chance to last until the death of partners and providing the model to follow for other couples.

Adult children of divorce have a very conservative view on the rules of marriage. Such a conclusion was brought by J.S Wallerstein, an American psychologist. "They despise the idea of informal relationships and - compared with their parents - they are morally more orthodox. Their return to traditional values does not result from roots in theology, but comes from their own acute sense of unhappiness arising from the experience of divorce" [Wallerstein, Blakeslee 2006, p. 47]. A different belief was revealed from my interviews, which I guess also comes from the experience of their parents' divorce. Many people stressed the lack of confidence in the institutional nature of marriage because they think it is not a guarantor of widely understood stability and durability 


\section{Maja Piotrowska}

of a relationship (they often expressed the conviction that "the paper doesn't give a guarantee"). I think that such a conviction comes from their own family experiences, where their parents' legalized marriage did not prevent them from the relationship breakdown. Also, those people's observations of social life, reports of increasing number of divorces and failed relationships among their acquaintances consolidate, I believe, their attitude towards the institution of marriage. These people have lost faith in the stability of marriage, and they still have this belief in their adult life.

"Exactly, there is some duality, because on the one hand I think this is something fantastic and actually I would love to have a husband, a man with whom I can be, and on which I can rely on, trust, as if having something stable in my life, a man that I know that this feeling will last forever! On the other hand... I don't believe that marriage can last forever. And it's not even the matter of what I've seen in my own home, but also what I see around, that actually such marriages rarely happen. I know cases of such successful, happy marriages, when, even if the couple is married, they are still together, they are not divorced, and then after a while, I have a feeling that they actually don't love each other any more, or they are together just because, well, because they have children, or... I don't know... They have no idea what to do, they aren't strong enough to divorce, or because "what would people say", or so, and as I look at my maternal grandparents, after all, they are married, but I think there were such moments that if my grandmother lived now, in the today's world, and in the city too, not in the country, she would divorce with my grandfather. So, what's the conclusion? It is that marriage is for me something which doesn't last. Moreover, knowing myself, I'm aware that it will be hard for me to live with one man, to trust him and be with him for so long and make this feeling actually last" (female, age 25).

Some of the opinions of my interlocutors expressed outright opposition and strong skepticism for a legally sanctioned marriage. According to these opinions, in order to be happy with someone, to start a family and raise children in an atmosphere of warmth, mutual trust and love one does not need to formalize the relationship:

"When it comes to marriage I'm pretty distanced. Frankly speaking, although I would like to start a family some day, I believe that in order to start a family, you don't need to get married. You can live together, you can be happy, and looking at it from my experience and observations concerning my friends - where they lived together for many years, then got married and finally divorced after a year or so - my opinion is that you can be happy together, but don't necessarily need to formalize it in the form of marriage" (male, age 25).

I think that such a conviction and lack of regarding the institution of marriage is today quite typical among young people. Krystyna Slany's research 
revealed that only $9 \%$ of respondents among the 1500 Polish students consider marriage as a permanent institution, while $51 \%$ believe it is the opposite [see Slany 2001]. Today, the concept of informal union is becoming an alternative for over 200,000 Poles. Transition from community-like family life, which, according to many famililogists, imposes on the person many barriers and restrictions, to "postmodern" society. Through new forms and ways of living, it may soon determine not only the demographic change in European countries, but also the undeniable impact on the state and development of the notion of family. Therefore, on the basis of these considerations, the following question appears: do we deal with the decline of marriage and family in our country? I think not. It is true that Poland, like most European countries, is subjected to the same sociocultural changes, often undergoes them, but our rooted tradition and attitude passed on from generations, that the family is as natural and universal institution of collective life, and - according to the survey of public opinion - is still something valuable among young people and adults [see Gawlina 2006]. I also think that we will inevitably witness the emergence of new family constellations, other than the well-known traditional forms of marriage-family life - a family to which we are so accustomed to. I think that these new forms of life are the sign of our times, times that Zygmunt Bauman calls "unstable modernity", and Anthony Giddens - "late modernity". It should be noted that marriage is such a form of human coexistence, which is subjected to constant evolution, which continues to alter its meaning for the people who get married. In traditional societies, it was the first purely economical agreement or contract. A husband used marriage as a base for his activities in the public sphere, while a wife dealt with raising children and taking care of house. Times of late modernity, particularly in the western societies, made marriage a context within which men and women can realize their needs for intimacy, love, equality and autonomy [Giddens 2006]. We are not able to prevent or avoid these changes. I guess that more important than the forms and structures which modern family is to adopt is the importance that people associate with this form of community life. So we need answers for such questions: what is a family for an average person and what value does it have for him or her? What does one mean by family life or married life, and what kind of sense it makes in the context of one's autobiographical and reflective history which influences the identity.

In my research, during discussions with adult children of divorce concerning the institution of marriage, I heard such statements, which, I believe, have to show the superiority of informal relationships on those legally sanctioned, statement like the one in which the interlocutor said that in free relationship a person must try a little bit harder in order to keep one's partner than when the relationship is formalized through a contract of civil and ecclesiastical means, which sanctions "the undying love". 


\section{Maja Piotrowska}

"I must admit that in some way, I do not understand the idea of marriage. Because I've actually thought that if people love each other they don't actually have to be so straightly linked. And often it is just like that, that people love each other and everything is $\mathrm{OK}$ and it is supposedly proved that after marriage suddenly everything slightly changes. I mean changes for the worse. It is known that there are couples who just do not have this problem, because they really love each other. And then, they get married, because of something, because they are older or they simply have to - in my opinion it is pointless, especially since most of these people maybe later, maybe after a few years, just splits up. Therefore, I do not understand the idea of marriage, I mean I understand, but on the other hand .. you know, well, because what sense does it make to get married without actually wanting to do it or so... I do not know, I have the impression that, when a couple love each other they do not need any additional papers or some symbols, and you know, some witnesses, promises that they were be faithful to each other. Because the truth is, I do not know how many percent, but probably many, that these people divorce after a few years, despite the fact that they promised love and faithfulness 'till the end of life. I think that this doesn't give promise, I really do not know what will happen to you or me in 10 years time. And at this point, you know, well, you know that someone can say "I love you", but no one knows what will happen in 10 years. Nothing guarantees anything, but I think that... I do not know, this is my impression that, in a free relationship people love each other more. Because they want to keep each other with themselves. And when you're married, it is so that you know you can sit in a chair and read a newspaper for the rest of your life, because someone promised to love you, right? It is no longer important, that you were like this or that, and suddenly you changes. But you know, it probably does work so. And from what I've heard many people, even on their wedding day, or several days after the wedding somehow totally change" (male, age 24).

"My mom is always laughing at me that I would probably never get married, that's my attitude towards it. For example, I do not see myself in a white dress, I just cannot stand it, you know? And besides, I am still saying: What's the point of getting married when one day you will probably want to divorce?" (woman, age 21).

In many statements of the adult children of divorce, there were opinions about temporality and impermanence of relationships, especially the married ones. It might be indicated by such an expression: "For me marriage is something impermanent, "cause most of these people later splits". I guess my interlocutors brought this belief both from their own experience as children whose parents divorced, but also from the observation of social life. Still increasing number of divorces in our country (on the basis of CSO data in 2009 there was record 
number of divorces - 72000 ) only strengthens this conviction. It creates a simple, yet sad consequence that since there is marriage, there also must be divorce. As I was told by one of the interviewees: What's the point of getting married when one day you will probably want to divorce? If the expectations towards marriage and your partner simply do not fit with everyday problems of living together you can start a new relationship with another partner. Thus, the concept of "pure relationship" (which actually can be broken at any moment) and "love of concurrent" Giddens pervades our society [Giddens 2007, p. 81].

For many of my interlocutors the concept of being in the informal relationship has become the optimal solution for their family life. There were also such statements, in which I found the acceptance for the both forms of relationship the legally sanction one which, according to my respondents, is important because after some time the couple have a child, and for the informal one without any contribution by church or law.

"When it comes to marriage, then yes, I respect both the people who do not get married and live together, as well as those who get married in church. I think that today it is easier for a child if everything is legitimate or ecclesiastically sanctioned. On the other hand, if people love each other and do not have any constraint that they must get married, and if you look at all those divorces, you can easily believe that this paper is worth nothing and it doesn't commit people to anything" (female, age 28).

"However now I think that marriage is important, important because of the children.

But I wish that our country would legalize the concubinage. That would eliminate all those potential problems people have when they don't want to live together any more, because something is wrong and it wouldn't be so difficult and tiring. When adults claim that: ok, we want to get divorced, therefore they should have a right to do it. I don't know, maybe some day I'll find someone with whom I would want to get married, and we will get married, but for now on I cannot imagine that, I cannot include it in any time frame or simply imagine it" (female, age 21).

“When I was younger I used to think that I don't need any paper, I don't need to go to the registry office, or even to the church (I'm not a very religious person), and then say "yes" in front of thousand or hundred people, or something like. I used to think that I really don't need all those things. At the moment, the situation forces me and my fiancé to get married, because he has some difficulties in getting to the country. But, actually I don't feel such a need, that I must go to the registrar's office and get married. Well, if I am to be with someone it isn't just for the paper" (female, age 25).

In these narratives also the issue of the document confirming the marriage of two people was discussed. Document, which - for many people I talked to 
- seems to be unimportant and really not giving any guarantee of a happy and lasting marriage. As one of the narrators said: "Observing how many divorces there are today, you can state that this paper actually doesn't commit people to anything. Another one added: Well, if I am to be with someone it is not just for the paper". I think that in the opinion of these people, this "paper" is just a cultural symbol, which they do not consider as significant, because it does not protect against breaking-ups, and what is worse - in the opinion of many - it only makes breaking-ups more difficult for the one who is not satisfied with the marriage.

We live in a culture that Zbyszko Melosik calls a culture of 'instant'. "It refers to the habit and the necessity of living in the "immediacy". The symbol of this culture is the famous triad of "Fast Food, Fast Sex, Fast Car" [Melosik 2000, p. 150]. We want everything and anything "immediately", and what stops us from "immediately" must to be eliminated. As an exemplification for this kind of culture we can consider a desire for freedom in all aspects of life, including those unbound by the institution of marriage, which after all, requires commitment and long-term relationship. Legally sanctioned marriage is, however, an obstacle to end the relationship in any time. The journey to achieve freedom again, to release from the partner with whom we do not want to be anymore, gets lengthened. The time which separates partners from the decision to end the relationship, to get free, the time that can be used to find a new partner or to start a new life - is wasted. As one of my narrators said "there are some problems people have when they don't want to live together any more, because something is wrong and it is so difficult and tiring". I believe that these words in some way reflect the atmosphere of our time in relation to "instant" culture. This statement still attracts attention for one reason - it ignores the issue of children, who the couple may have during the relationship. Then, one can not speak of an immediate break from, family ties which have been already established by time. Moreover the process of decay, caused by mainly selfish need to get free from the unwanted partner, cannot be painless, fast and easy. The fact that the couple have a child changes the perception of the situation, already narrowed to only two adults. It extends it and, according to me, also takes responsibility for the welfare of a minor person.

\section{The importance of family in the narratives of children of divorce}

As famililogists reported - and this view is confirmed by many public opinion polls - the family is still considered to be one of the most important values for contemporary Poles. My conversation with the adult children of divorced parents, and collected research material also seem to confirm this thesis. However, in my opinion, the stigma of divorced parents is still present in the statements of many of these people, and in some way affects their views on family and the importance that they give to this smallest and also the basic social group. 
Contemporary family, just like the institution of marriage, is subjected to many socio-cultural changes. Our opinions about it are constantly changing. However, for centuries we have expected the notion of family to give us a shelter, a typical oasis of peace, where our sorrows, worries would be soothed, where we would find friendly people who would care about our welfare. Family would be a kind of heaven in the always busy, fast, and sometimes full of hostility outside world.

In the expressed opinions regarding the family, these narratives revealed that my interlocutors associate a great importance with this notion. On the basis of these statements one could distinguish the meaning of family and what this smallest unit of society is for them. Those people associate the importance of family with the categories I will try to describe below. They concern: a sense of security one can experience in the family, meeting place with other people that family offers, and the strength of blood ties that always work in the face of life difficulties, allowing to count on the help and support of family, when we need them, as well as a sense of existence that we experience by participating in family life.

Leitmotiv, appearing in a lot of my interlocutors' narratives was the sense of security. Security which is sought and sometimes found precisely in family structures. That is how my interlocutors said about it:

"Family is something important in everyone's life, or at least it should be. It gives some sense of community, and that you always have a home to go back and feel safe. And it is important that you can feel secure there. So it should be like that - you are aware that there are people who care about you and love you. On the other hand, looking at the modern family, a person starts to wonder whether it is worth to start a family, if family members treat each other like some strangers, make them suffer and then divorce for whatever reason" (female, age 28).

"Certainly I feel respect for the family. This is such a place where one can feel secure. I know people who, well, they are a happy family, live together, who have changed under their influence and can live normally. But on the other hand, more often I see people who are divorcing. And I don't know what to think about it. I have such mixed feelings all the time" (female, age 21).

The need for a sense of security is one of the basic psychological and social needs. Satisfying this needs, according to many authors of works devoted to the family, begins in early childhood and is especially shaped by our parents [see Ryś 1999]. This sense of security can be found in the knowledge that is certain, routine and not problematic. Giving the impression of a correct image of reality, it is one of the available conditions of being in the world. As Mirosława Nowak-Dziemianowicz writes, "from some solid fragments of reality a human requires support of one's deeds, existence and identity. A person needs some solid knowledge which cannot be questioned or complicated (...). In order not to get 


\section{Maja Piotrowska}

lost in a complex, diverse and full-of-contradictions world a human needs some knowledge that gives a sense of rightness and the answers to questions on the basis of one can feel secure in the world, like "at home" [Nowak-Dziemianowicz 2002 , p. 78]. However, such an understanding of sense of security may be quickly undermined and severely violated by the person who lives in times of changing modernity. The above statements also revealed this aspect of modern family life which is associated with its instability (as in the case of views on marriage). According to my interlocutors, today's families are transient, intermittent and prone to disintegration of their structures. Today, sense of community, which is one of the manifestations of family life and one of the most important features literature gives to family, gets violated. I think that these narratives revealed such a duality in my interviewee's opinions about family. On the one hand they emphasized the value and strong need for the sense of security family can provide. On the other hand they are aware of impermanence and fragility of family structures that may destroy this sense of security, and they are afraid of it. I think that if a person wants to live in today's world, he or she needs to find the appropriate tools by which one would be able to handle with those inevitable fears and concerns.

In another approach to the notion of family, my interlocutors emphasized the aspect of blood ties linking members of the family:

"Well, certainly family is most important than anything, however, you must value it. Let's put this on, as a matter of fact a friend can betray you, etc. A family is a family. People tend to say it is good to be with family but only on the photo picture. Even though among your family you'll always find someone who will help you, on who you can count on. It's a matter of blood ties" (male, age 23).

Emphasized in this way, the importance of blood ties is, according to my interlocutor, to give a sense of confidence of the possibility to get help and support from family, when a person finds oneself in a difficult situation. In this approach family is the circle of people who you can always ask for help and get it, precisely because of the ties connecting people and family affinities. Such a belief in some kind of commitment and a sense of belonging and security, which each member of the family community associates to their relatives, gives family - as I understood - the greatest importance. As noted by the narrator, family is more important than friendship and one must value it. Urszula Sokal's studies show that both women and men from divorced families, in their adult life give the category "Family Safety" (emphasized by her) the most important rank among the ultimate values of the scale developed by M. Rokeach. The author of the scale defines the final values as the most important goals of human life. The results of U. Sokal's research show that among the other values "family safety" was placed as the first one by $42,4 \%$ of the women (22.7\% as the second) and $43.3 \%$ of men. 
In the system of ultimate values these people place family and related with it safety on the highest position [Sokal 2001, pp. 161-176].

A lot of my narrators consider family community as something most important, giving meaning to the world of human existence. One of the respondents expressed his opinion as follows:

"A family is a very important issue, it is something most important in one's life. Because when you don't have family, whatever you do means nothing. Subjects of your interest only completes what your family is to give you. I do not know, for example some martial arts champion is 50 years old and is indeed the best at what he does, no one can compete with him. But after all he doesn't have a family. He is alone. He travels from one country to another, from town to town. Often he finds some new lovers or girlfriends. I don't know what he thinks about it, we should ask him. But for me life like this doesn't make any sense" (male, age 25).

Adult children of divorced parents think of family as a great value. It is often expressed in the belief that everything else in life (wealth, career, etc.) really does not mean anything when a person does not have anyone to be with, to be loved by, for who can live and try. It all becomes meaningless and does not give true happiness and fulfillment. "Because whatever one does, subjects of interest only complete what a family is to give" - said one of the participants in my research. I believe that such belief has its source in those people's own family experiences. They have experienced by themselves what it means to live in the "incomplete families" together with the implications of growing-up in such a structure. These sad experiences from childhood are manifested in a reflection on the meaning of family life and its value for everyone. In my opinion, the awareness of the losses caused by parent's separation, makes them value the notion of family when they are about to start their own one.

The last perception and definition of the family, which was revealed in a conversation with the adult children of divorce was family as a meeting place with other people. One of the narrator's statements can function as an exemplification of such a definition and meaning of family:

"Family... I think it is needed. Well, it is connected with the society, there is some pressure, Imagine that everyone, maybe your friends are getting married and will start a family. You think - "I will also do that." You cannot expect your friends who have family to spend with you as much time as before and you start thinking about having your own family. Because then you would have such a place where you could always come back and be happy. There you would find other friendly people. Of course, it is quite obvious that there will be some difficult times, but if you think about it, you'll realize that through all this time you can create something really cool" (male, age 24).

Family seen as a meeting place with other people, as a structure that protects a person from loneliness, as a "construction site" of something important, valuable 
for human existence embedded in the long term - these were my interviewee's descriptions of family.

I think that this meeting place with other people is a place, where our beloved ones, give meaning to our lives, become the driving force and the axis of life in all our aspirations and actions. This is a special place where joys and sorrows of everyday life intertwine with each other, where we learn to respect understanding and acceptance of otherness, which the other person presents. "Of course, it is quite obvious that there will be some difficult times, but if you think about it, you'll realize that through all this time you can create something really cool" said one of the participants of my research.

\section{Conclusion}

We live in a world where all the beliefs, passed from one generation to another, all our values are being redefined. Notions of marriage and family also receive different meaning. In still-changing modernity human relationship take various form, new constellations are being created. Today, the term „marriage” extends its meaning, not limiting itself to the naming of „entangled” couples by legal or church law. It also refers to people who consider themselves to be linked with each other, not only by legal terms, people whose relationships are different on various levels from the traditionally understood marriage. It is still reflected in the emerging of new forms of marriage-family or quasi-family life. However, for generations we have invariably associated the notion of family with love, support, warmth and place of meeting with people important and valuable to us, on who we can count on and expect some help when we need it.

Such an importance given to the family was revealed in my interviews with the adult children of divorced parents. People involved in my research often stressed the great value they associate with this smallest social group. I think that their opinions and beliefs are the consequence of the fact that my interlocutors - as they admitted - did not experience by themselves things they were talking about. As one of my narrators said in a very sad way: "Both me and my brother, because of all those things we've been through, consider home as something important, something you must take care of". On the other hand their opinions about marriage and family are full of uncertainty and fear of impermanence that these two so much important form of linking people together brings to the adult person. They seem not to believe that their relationships can last forever. Especially marriage is for them something impermanent, weak and unstable, something likely to decay. Memories concerning their parents' divorce are for them notions to prove their theories.

The period of early adulthood, in which my narrators are, brings with itself the time of reflection on the past. Statements about marriage and family seem to 
be firmly rooted in the past experiences, which is reflected in their convictions concerning the impermanence of marriage and family systems. On the other hand, one can notice an intense longing for what they could not experience in the past - a stable and happy family. I believe that in the context of the presented narrations one can conclude that the divorce of the parents as the critical life event is strongly written in the identity of "the children of divorce". It highly influences their attitudes towards marriage, family and relationships in general.

\section{Bibliography}

Beisert M. (2000), Rožwód. Proces radzenia sobie z kryzysem, Wyd. Fundacji Humaniora, Poznań.

Franicka M. (1999), Jak sobie poradzic z rozwodem rodzicón (wg koncepiji Wallerstein), „Problemy rodziny", nr 2-3.

Gawlina Z. (2006), Matžeństwo i rožwód w opinii młodžię̇y, „Roczniki Socjologii Rodziny”, t. XVII.

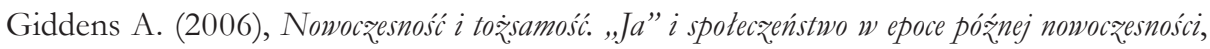
PWN, Warszawa.

Giddens A. (2007), Pržemiany intymności. Selesualność, mitość i erotyzm we wspótczesnych spoteczeństwach, PWN, Warszawa.

Kawula S. (2006), Ksæztałty rodžny wspótczesnej. Sžkice familiologiczne, Wyd. Adam Marszałek, Toruń.

Kvale S. (2004), Inter Viens. Wprowadzenie do jakościowego nywiadu badawcrego, Trans Humana, Białystok.

Kwak A. (2005), Rodżina w dobie przemian. Mak̇̌eństwo i kohabitacja, Wyd. Akademickie „Żak”, Warszawa.

Melosik Z. (2000), Kultura „instant” - paradoksy pop to:ssamości, Teraźniejszość - Człowiek - Edukacja, Numer specjalny.

Nowak-Dziemianowicz M. (2002), Doświadczenia rodżinne w narracjach. Interpretacja sensów $i$ znaczeń, Wyd. Uniwersytetu Wrocławskiego, Wrocław.

Pszczółka K. (2005), Uwagi o niektórych problemach wspótczesnej rodziny [w:] Rodžina. Historia i wspótczesność (red.) W. Korzeniowska, U Szuścik, Impuls, Kraków.

Ryś M. (1999), Wptyw džiecinstwa na życie doroste [w:] Studium rodžny (red.) T. Rzepecki, Oficyna Współczesna, Warszawa.

Slany K. (2001), Orientacje matżeńskie i rodžnne mtodzieży akademickiej, „Problemy rodziny”, $\mathrm{nr} 3$.

Sokal U. (2001), Wartościpreferowane przez osoby dorostepochodzace z rodzin petnych i rozwiedzionych, „Roczniki Socjologii Rodziny”, t. XVII.

Tyszka Z. (2001), Relacja „rodżina-spoteczeństwo globalne” w okresie transformacji, [w:] Rodzina wspótczesna (red.) M. Ziemska, WUW, Warszawa.

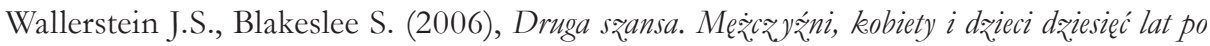
rozwodzie, Wyd. Charaktery, Kielce. 